\title{
Labor productivity in digital agriculture
}

\author{
Asiya K. Subaeva, Marat M. Nizamutdinov*, Leysan M. Mavlieva, and Marat N. Kalimullin \\ Kazan State Agrarian University, 420015 Kazan, Russia
}

\begin{abstract}
The article provides information on the labor productivity level in the agricultural sector, reveals aspects of innovations in production, analyzes the education level in human resources of rural workers, reveals the prospects for digitalization of the agricultural sector.
\end{abstract}

\section{Introduction}

The study of the concept of "productivity" can be interpreted differently depending on the goals and objectives of a specific economic analysis. In a general sense, productivity is considered as the level of application of all resource types, contributing to the growth of profits and profitability of the enterprise [1].

Regarding the growth of labor productivity, this concept provides for fruitfulness, the ability of a labor to create a certain number of products or services per unit of working time [2].

The labor spent for the production of goods and services consists of present and past labor, embodied in the earlier produced goods used to produce new products [3].

The concept of "labor productivity" in the digital economy should be considered as an indicator of people's effective activity, determined by the quantity and quality of manufactured products per unit of working time, depending on the level of technical, technological and informational development of production, the level of innovative literacy of the workers (education, competence, learning ability).

\section{Methods}

In modern conditions of economic development, the question arises of a significant improvement in the quality and growth of labor productivity. This is the most important condition for ensuring the economically correct correlation between the growth rates of labor productivity and wages [4].

The increase in labor productivity is directly related to the following indicators: output and labor intensity. The development of an indicator of accounting for the level of labor productivity. Depending on the units in which the volume of work performed, and the hours worked are measured, several methods for calculating the level of production are distinguished.

The natural method of calculating output show the volume of in physical units. This method most clearly characterizes the level of labor productivity, however, it is applicable only for homogeneous products [4].

The conditionally natural method of calculating output expresses the volume of work in conditionally natural units. The conditionally natural method is applicable for calculating the indicator of labor productivity in the production of heterogeneous, but similar products [4].

The labor method of measuring labor productivity shows the volume of work in the working hours. The labor method is applicable to all types of products, regardless of their degree of readiness and is widely used in the study of the relative changes in labor productivity. However, this method requires the stability of the applicable standards, while the latter are constantly changing as the organizational and technical working conditions improve.

The most common method in practice is the cost method of measuring labor productivity, based on the use of cost indicators of the output volume. The advantage of this method is the possibility of comparing heterogeneous products with the costs of their manufacture both within the framework of one enterprise, industry, and throughout the country $[1,4]$.

With the cost method, labor productivity is calculated by dividing the volume of output by the average number of employees.

The cost method of measuring labor productivity has several varieties depending on the different cost expressions of the products produced (commodity, gross, sold, net, normative-net production, standard cost of processing).

Labor productivity indicators calculated on gross, commodity, sold products have similar advantages and disadvantages. Their main drawback is that these indicators are interconnected with a change in the range of products, the cost of raw materials and materials, a change in the specific gravity of semi-finished products, components obtained from other enterprises, while the production rate may increase or decrease. Changes in the level of labor productivity may in such cases be unrelated to the improvement or deterioration of the activity of the enterprise [4].

Corresponding author: marat181@ rambler.ru 
The essence of the method of measuring labor productivity based on the standard cost of processing is that not the wholesale price is accepted for estimating the volume of output, but only the part which conditionally characterizes only the cost of living labor. The indicator of the standard cost of processing does not include the cost of materials, semi-finished products, general and general production costs, that is, that part of material costs, the value of which mainly depends on the activities of this enterprise.

The standard cost indicator of processing does not consider the surplus product. This is considered a disadvantage.

\section{Results}

The problem of the Russian labor market is the low level of labor productivity, according to which Russia remains 3-4 times behind the countries of world leaders. The Russian labor market is developing amid a decline in the economically active population. For this reason, one of the most important requirements for the labor market and the economy is to reach a fundamentally new level of labor productivity [5].

Studies on the agricultural workers' education level in the Republic of Tatarstan showed a certain positive trend in the dynamics and structure of labor demand in the industry within 2009-2017 and an increase of workers with higher and secondary specialized education (Fig. 1, Tab. 1).

According to the data in Table 1, the proportion of managers with higher education in 2017 compared to 2009 increased by 2.4 percentage points.

There is a similar situation in the category of specialists in personnel of mass professions, the proportion of which with higher education grew by 1.9 percentage points. In general, $44.4 \%$ of managers and specialists of agricultural organizations have higher education.

Table 1. Education level of managers and specialists in agriculture of the Republic of Tatarstan, \%

\begin{tabular}{|l|c|c|c|c|c|}
\hline Personnel Categories & 2009 & 2011 & 2013 & 2015 & 2017 \\
\hline Managers and specialists & 100.0 & 100.0 & 100.0 & 100.0 & 100.0 \\
\hline obtained: & & & & & \\
\hline $\begin{array}{l}\text { - higher professional } \\
\text { education }\end{array}$ & 46.8 & 42.8 & 42.5 & 42.4 & 44.4 \\
\hline $\begin{array}{l}\text { - secondary vocational } \\
\text { education }\end{array}$ & 45.8 & 45.7 & 45.5 & 44.6 & 43.3 \\
\hline $\begin{array}{l}\text { - do not have higher or } \\
\text { secondary vocational } \\
\text { education }\end{array}$ & 11.0 & 11.5 & 12.0 & 13.0 & 12.3 \\
\hline $\begin{array}{l}\text { Level of education for } \\
\text { personnel in mass } \\
\text { professions }\end{array}$ & 100.0 & 100.0 & 100.0 & 100.0 & 100.0 \\
\hline $\begin{array}{l}\text { obtained: } \\
\text { - higher professional } \\
\text { education }\end{array}$ & 0.9 & 1.8 & 2.2 & 2.5 & 2.8 \\
\hline $\begin{array}{l}\text { - secondary vocational } \\
\text { education }\end{array}$ & 28.6 & 28.0 & 26.1 & 25.5 & 28.1 \\
\hline $\begin{array}{l}\text { - primary vocational } \\
\text { education }\end{array}$ & 36.8 & 36.5 & 34.4 & 35.9 & 36.0 \\
\hline $\begin{array}{l}\text { - course plant or training in } \\
\text { production }\end{array}$ & 14.8 & 14.0 & 12.1 & 10.5 & 9.5 \\
\hline $\begin{array}{l}\text { - do not have professional } \\
\text { education }\end{array}$ & 23.9 & 24.1 & 23.7 & 24.1 & 23.6 \\
\hline
\end{tabular}

However, the lack of professional education in $20 \%$ of agricultural workers amid the intensive development of scientific and technological progress is alarming.

Among professional groups of workers, machine operators and drivers have a higher qualification level. Thus, an analysis of the personnel in agricultural organizations in the Republic of Tatarstan shows the proportion of the first class machine operators was $62 \%$ of their total number, drivers $-60 \%$. The data is taken from the statistics in 2017.

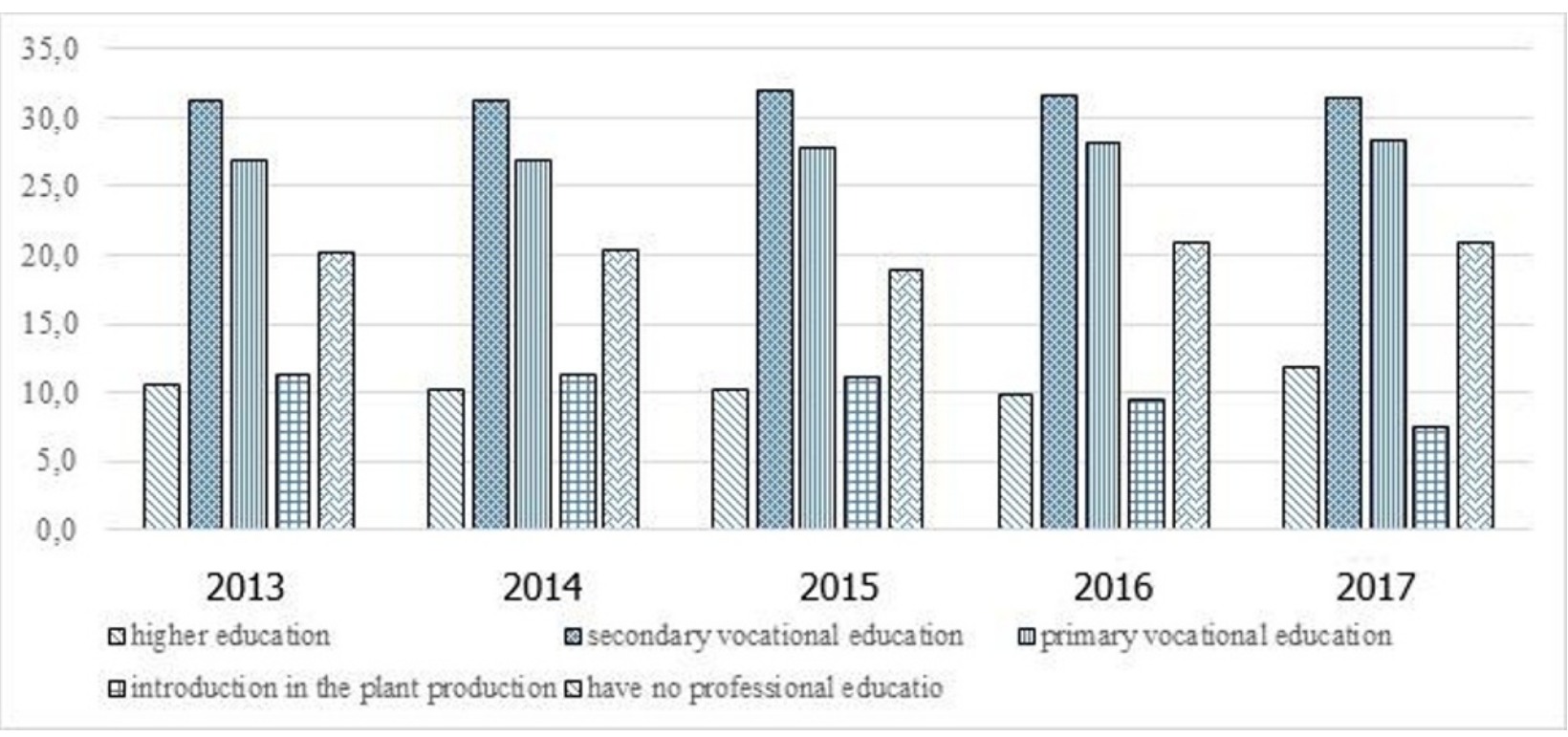

Fig. 1. Distribution of the number of employees by the level of education in agriculture (in $\%$ of the total) $\%$ 
In the case when due to the increase in the technical equipment of labor, its better organization, growth in the cultural and technical level of workers, the labor productivity of managerial workers changes significantly, even a significantly increased volume of production management functions can be performed by the previous or even smaller administrative and management personnel. Therefore, when planning the states, it is necessary to establish reasonable intervals for the relevant standards for the number of administrative and management personnel [4].

The number of agricultural organizations with qualified workers and specialists is not the same: a professional-qualification imbalance of supply and demand is observed. In addition, a decrease in demand is simultaneously accompanied by a shortage of supply of qualified personnel and their weak localization. Studies have shown that, despite enough trained specialists, agricultural organizations cannot fully provide themselves with labor resources. The reason is not the number of trained personnel, but the turnover.

To solve the problem of increasing labor productivity, it is necessary to implement measures related to increasing the efficiency of agriculture: increasing incomes, increasing education, automation and mechanization, chemicalization and land reclamation, intensifying and transferring the industry to high-tech methods, etc., which will require and create the basis for educational growth of the rural population.

At present, as the factors of extensive economic development are exhausted, increasing labor productivity in agriculture is becoming a key condition for economic growth and ensuring food security in Russia on the world market, however, to achieve these goals, it is necessary to change both the current state of organization of agricultural production and personnel potential sat down.

\section{Conclusion}

Increasing labor productivity is a complex process that occurs under the influence of different factors. However, the impact of all groups of factors in the complex increase in labor activity of workers can be achieved only by creating a new economic mechanism of management and the formation of new economic relations on its basis.

There is an idea of the scheme tools for increasing labor productivity in agricultural enterprises in Fig. 2.

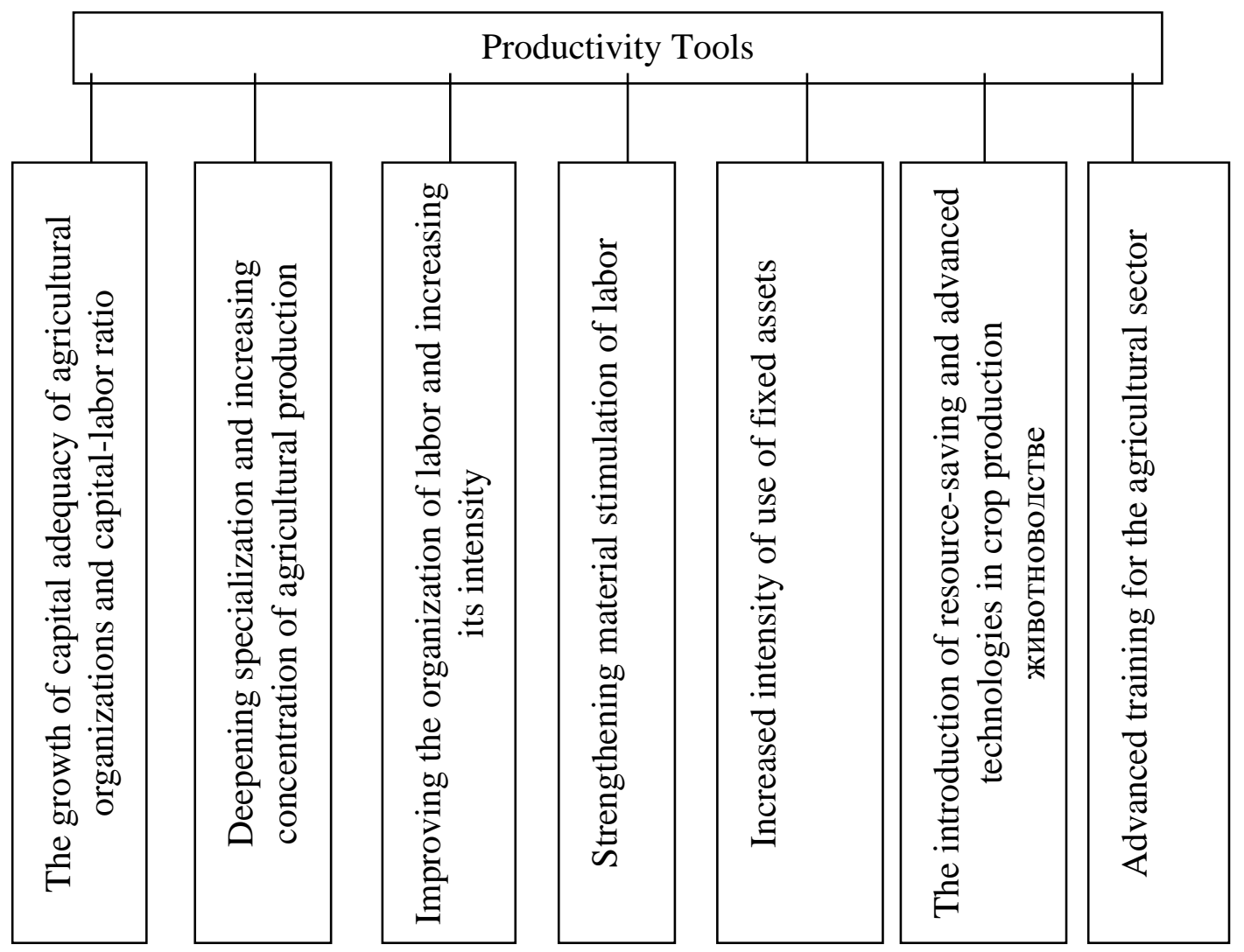

Fig. 2. Tools to increase labor productivity in agricultural enterprises

Technical staffing in agriculture is the material basis for raising labor productivity. Technological progress is an important process for the phased replacement of living labor by the work of the most active part of the basic production assets, such as machinery and other equipment. It is manifested in an increase in the quantity and quality of agricultural machinery. So, by 2016, more than $30 \%$ of technical means: combines, milking and harvesting machines were replaced and improved at agricultural enterprises of the Abansk Region [1]. 
Labor productivity also depends not only on the capital-labor ratio, but also on the effective and intensive use of fixed assets.

The intensive use of tractors, combine harvesters, and trucks help to reduce their downtime for some reason and helps to increase production per unit of equipment by about $19-26 \%$ [1].

The rational specialization and strengthening of agricultural production to the optimum size contributes to a more efficient use of machines, mechanisms, material and labor resources. Expensive and highperformance digital technologies can be used with maximum load in large specialized farms. This will significantly increase the gross agricultural output and reduce the complexity of its production.

A decrease in the complexity of production is also observed with the introduction of intensive and advanced technologies in agriculture. If you apply intensive technologies in crop production, you can ensure a reduction in costs per unit of production by about 19-23\%. This can be achieved by using more digital technologies, new varieties of crops or fertilizers in agricultural production [1].

The use of intensive and new industrial technologies requires the rational organization of labor. The organization of labor in enterprises must be structured in such a way as to facilitate the efficient use of labor resources and the growth of labor productivity.

The lower level of labor productivity in animal husbandry compared with crop production is explained not only by the varying degree of mechanization of labor-intensive processes in industries, but also by organizational reasons.

In livestock breeding, there is a mismatch between the forms of division and cooperation of workers in primary and secondary professions with the progressive level of mechanization of production and the requirements of advanced technologies. This leads to a difference in the degree of congestion of milkmaids and cattle. Labor productivity in livestock production depends on the sanitary and hygienic criteria of manufacture and the microclimate in livestock buildings [1].

Thus, enterprises that maximize the potential of science, realize world-class scientific and technological progress in their work, use a combination of organizational, managerial, socio-economic and moralpsychological principles of labor motivation and have highly qualified specialists, can effectively compete in the direction of increasing labor productivity, able to provide the country with sufficient food and create food security foulness.

\section{References}

1. V.T. Vodyannikov, A.K. Subaeva, Scientific and technological progress and labor productivity in the agricultural sector of the economy (Brig, Moscow; Kazan, 2018)

2. V.A. Makarova, The development of the organizational mechanism for increasing labor productivity of mining workers, $\mathrm{PhD}$ dissertation (Chelyabinsk, 2014)

3. I.V. Krasnopevtseva, Management of labor productivity in engineering enterprises, $\mathrm{PhD}$ dissertation (Saratov state technical university named after Yu.A. Gagarin, Saratov, 2015)

4. T.M. Levchenko, A.F. Shupletsov, Indicators and methods of measuring labor productivity, Successes in modern sci., 2, 85-86 (2007)

5. V.E. Tishchenko, Organization and planning of exploration for oil and gas, textbook, 2rd ed. (Nedra, Moscow, 1977)

6. Statistical Yearbook of the Republic of Tatarstan2017: collection / Terr. on the fed. state statistics service in the Republic of Tatarstan (Tatarstanstat, Kazan, 2017)

7. M.A. Sysoev, T.I. Ashmarina et al., Innovations in the process of reproduction of agricultural machinery, monograph (Publishing house of Melitopol city printing house, Melitopol, 2013)

8. A. K. Subaeva, M. M. Nizamutdinov, Technical equipment of the village as a factor of the environment of direct and indirect impact on the financial results of the enterprise, Modern probl. of sci. and ed., 1 (2015) Retrieved from: http://www.science-education.ru/121-17727

9. Official site of the Ministry of agriculture and food of the Republic of Tatarstan. Retrieved from: http://agro.tatarstan.ru/rus

10. GOST R 53056-2008 Agricultural Machinery. Methods of economic assessment. Retrieved from: http: / / www. docme. ru / doc/157881/gost-r-530562008-tehnika-sel. 